\title{
Prevalence of vitamin $D$ deficiency during the summer and its relationship with sun exposure and skin phototype in elderly men living in the tropics
}

\author{
This article was published in the following Dove Press journal: \\ Clinical Interventions in Aging \\ 2 October 2013 \\ Number of times this article has been viewed
}

\author{
Marcelo Azevedo Cabral \\ Carla Núbia Borges' \\ Juliana Maria Coelho Maia' \\ Caio Augusto Martins \\ Aires ${ }^{2}$ \\ Francisco Bandeira ${ }^{3}$ \\ 'Department of Clinical Medicine, \\ University of Pernambuco Medical \\ School, ${ }^{2}$ Department of Biomedicine, \\ University of Pernambuco Medical \\ School, ${ }^{3}$ Division of Endocrinology, \\ University of Pernambuco Medical \\ School, Recife, Brazil
}

Objective: The aim of the study reported here was to determine the prevalence of vitamin D deficiency among elderly men and its association with sun exposure and skin phototypes.

Subjects and methods: This was an analytical cross-sectional study, which involved 284 men aged 60 years or over, randomly recruited from a basic care unit in the city of Recife (Brazil). Measurements: Serum levels of 25 hydroxyvitamin D $(25(\mathrm{OH}) \mathrm{D})$, sun index, and skin phototypes were evaluated.

Results: The prevalence of vitamin D deficiency was $31.5 \%$ and $66.7 \%$ when cut points of less than 20 and $30 \mathrm{ng} / \mathrm{mL}$, respectively, were used. Mean serum 25(OH)D was $27.86 \pm 13.52$ standard deviation $(\mathrm{SD}) \mathrm{ng} / \mathrm{mL}$. There was no difference $(P=0.113)$ in $25(\mathrm{OH})$ $\mathrm{D}(23.98 \pm 14.66 \mathrm{SD}$ vs $29.88 \pm 13.78 \mathrm{SD})$ between individuals in the lowest quartile $(\mathrm{Q})$ of the sun index (Q1: 1.96) compared with those in the highest (Q4: 7.86). When considering a cutoff of $20 \mathrm{ng} / \mathrm{mL}$, the sun index was different in the two groups $(P=0.006)$, but there was no difference when cutoffs of 25 and $30 \mathrm{ng} / \mathrm{mL}$ were used. After adjustment, sun index and body mass index were associated positively and negatively, respectively with serum 25(OH)D independently. Most subjects (66.7\%) had Fitzpatrick's skin phototypes IV, V, and VI. Low calcium intake was observed in $72 \%$. There was no difference in serum $25(\mathrm{OH}) \mathrm{D}$ levels between patients with low intake and those with intermediate and high intakes. Only $2.5 \%$ were taking a vitamin supplement.

Conclusion: We found a high prevalence of vitamin D deficiency among elderly men despite their high sun exposure during the summer months.

Keywords: sun index, serum 25(OH)D levels, body mass index, Brazil

\section{Introduction}

The discovery that the majority of body tissues and cells harbor vitamin $\mathrm{D}$ receptors and that several possess the enzymatic equipment to convert the primary form in circulation into the active form, has provided new insights into the function of this steroid hormone. There is great interest in the role that vitamin D can play in many chronic diseases, including common cancers, autoimmune, infectious, and cardiovascular. ${ }^{1-3}$

The sources of vitamin D are primarily the cutaneous production and food intake. In Brazil, the dietary source is scant, since foodstuffs such as fatty fish are not available in tropical and subtropical climates. There are no official recommendations in Brazil on the fortification of foods with vitamin D. ${ }^{4}$

Elderly populations present certain particularities. With aging, solar exposure is generally limited in view of the changes in lifestyle, such as clothing and activities 
outside the home. Diets may become less varied, with lower vitamin content. However, more important is the lower cutaneous production of vitamin D with aging, due to the atrophic skin alterations with greater availability of the precursor 7-dehydrocholesterol. Among other factors, the production of 1,25-dihydroxyvitamin D3 diminishes as a result of the decrease in kidney function with aging. ${ }^{5-7}$

Several cutoffs related to the blood levels of 25-hydroxyvitamin $\mathrm{D}(25(\mathrm{OH}) \mathrm{D})$ have been proposed to define deficiency/insufficiency in asymptomatic individuals. This is partially due to the variability of the concentration of vitamin D according to geographic location and the different methodologies employed in the various studies. ${ }^{8,9}$ In northeast Brazil, Bandeira et al found significant differences in the bone mineral density and in the serum levels of parathyroid hormone, with 25(OH)D values below $25 \mathrm{ng} / \mathrm{mL}$ in postmenopausal women. ${ }^{10}$ Ensrud et al, in a large American cohort, demonstrated that 25(OH)D levels below $20 \mathrm{ng} / \mathrm{mL}$ were associated with significant hip bone loss in older men, when compared with higher levels, but this loss was not found in younger. ${ }^{11}$ Other studies have demonstrated that levels above $32 \mathrm{ng} / \mathrm{mL}$ are necessary for an adequate intestinal absorption of calcium. ${ }^{12,13}$

Although the literature reveals a high prevalence of vitamin D deficiency in the elderly, as far as we are aware, no consistent population studies in the tropics have evaluated its prevalence in elderly men and its relation to sun exposure and skin phototypes.

\section{Methods}

\section{Study design and participants}

This was an analytical cross-sectional study, which involved 234 men aged over 60 years of age, randomly recruited from a basic care unit in the fifth health district (5th HD) of the city of Recife in the state of Pernambuco, during the Brazilian summer months, from October 2010 to January 2011. The city of Recife is divided into five health districts. The 5th HD was chosen because it caters mostly for the elderly.

The patients eligible for the study were free-living individuals (people who are not living in an aged care institution), able to walk unaided and who had not used drugs such as corticosteroids for prolonged periods (doses $\geq 2.5 \mathrm{mg}$ of prednisone or equivalent for over 3 months), anticonvulsants, or lithium for 1 year. Subjects with metabolic bone diseases and active neoplasms, except neoplasms of the skin such as basal cell and spino-cellular cancer, were excluded.

The study protocol was approved by the Ethics in Research Committee of the Agamenon Magalhães Hospital.

\section{Definition of the study variables}

Demographic and economic data, medications, calcium intake, and vitamin supplements were evaluated by means of a questionnaire. Exposure to the sun was calculated using the sun index (SI; fraction of the area of the body surface exposed multiplied by the number of hours of sun exposure per week). ${ }^{14}$ Skin phototypes were classified into six types, according to Fitzpatrick's classification (type I being the lightest and type VI the darkest). ${ }^{15}$ Daily calcium intake was defined by asking patients to advise their calcium intake from food and supplements and classified as follows: low = intake below two portions $(250 \mathrm{~mL})$ per day of milk and/or dairy products and without calcium supplements ( $<600 \mathrm{mg} /$ day); intermediate $=$ intake of two or more portions without calcium supplementation (600-1,000 mg/day); and high = daily calcium supplementation and the consumption of milk and/or dairy products $(>1,000 \mathrm{mg} /$ day $) .{ }^{16}$ When the individual did not have a calcium intake from diary but used supplements, calcium intake was classified according to the calculation of the amount of calcium contained in the supplement. In Brazil, the recommended intake of calcium is $1,000 \mathrm{mg}$ daily. The questionnaire also asked whether the patient was using vitamin supplements containing vitamin $\mathrm{D}$.

Serum 25(OH)D levels were measured by electrochemiluminescent competitive immunoassay using a DiaSorin LIAISON $^{\circledR}$ analyzer (Turin, Italy), with the inter- and intraassay coefficients of variations of $8 \%-15 \%$ and $8 \%-13 \%$, respectively and a minimum limit of detection of $2 \mathrm{ng} / \mathrm{mL} .{ }^{17}$ Measurement of $25(\mathrm{OH}) \mathrm{D}$ by immunoassay is considered the method of choice for reasons of convenience, speed, turnaround, and cost. ${ }^{17}$

\section{Statistical analysis}

For the description of the prevalence rates, the percentages and respective $95 \%$ confidence intervals were recorded using the binomial method. Pearson's chi-square test and Student's $t$-test with equal or unequal variances were used for percentage and mean comparisons.

Adjustments were made by means of multivariate linear regression. The model was performed with stepwise selection of variables, maintaining in the model the variables with a significance of up to $15.0 \%(P<0.15)$. The following independent variables were studied: age, annual income, grouped skin phototypes (Group 1: skin types I-III; Group 2: skin types IV-VI), calcium intake, and body mass index (BMI).

The level of significance applied in the statistical tests was $5 \%$. The statistical significance tests were two sided. 
SPSS software (v 15.0; IBM Corp, Armonk, NY, USA) was used for the statistical calculations.

\section{Results}

The clinico-epidemiological characteristics of the elderly patients studied are shown in Table 1. The mean age was $69.4 \pm 6.5$ years (mean \pm standard deviation $[\mathrm{SD}]$ ) and the majority (66.7\%) had dark skin (type IV, V, or VI of Fitzpatrick's classification). When comparing prevalence according to skin type (dark vs light) for each serum 25(OH)D cutoff ( $<20,<25$, and $<30 \mathrm{ng} / \mathrm{mL}$ ), we found no significant difference $(P=0.46)$. Only $2 \%$ reported use of vitamin D supplements. Using cutoffs for serum 25(OH)D levels below 20 and $30 \mathrm{ng} / \mathrm{mL}$, the prevalence of vitamin D deficiency was $31.5 \%$ and $66.7 \%$, respectively (Figure 1). Mean serum 25(OH)D was $27.86 \pm 13.52 \mathrm{ng} / \mathrm{mL}$ (mean $\pm \mathrm{SD}$ ). After stratification according to age group (60-69, 70-79, and $\geq 80$ years), no difference in the prevalence of vitamin $\mathrm{D}$ deficiency was found between them.

The mean SI was $5.49 \pm 5.05$ (mean $\pm \mathrm{SD})$. There was a significant difference $(P=0.006)$ between SI means in the groups with serum 25(OH)D levels below and above $20 \mathrm{ng} / \mathrm{mL}(4.46 \pm 3.69$ vs $6.01 \pm 5.54)$. However, for the cutoffs of $25 \mathrm{ng} / \mathrm{mL}(5.07 \pm 4.31$ vs $5.95 \pm 5.69)$ and $30 \mathrm{ng} / \mathrm{mL}$ (5.22 \pm 4.43 vs $6.12 \pm 6.14)$, no significant difference was found. Considering SI values divided into quartiles (Qs), the

Table I Baseline characteristics of participants $(\mathrm{N}=284)$

\begin{tabular}{ll}
\hline Variable & $\begin{array}{l}\text { Results (mean } \pm \text { SD } \\
\text { or } \mathbf{N}[\%])\end{array}$ \\
\hline Age (in years) & $69.44 \pm 6.49$ \\
BMI $\left(\mathrm{kg} / \mathrm{m}^{2}\right)$ & $25.67 \pm 4.31$ \\
Sun index & $5.49 \pm 5.05$ \\
$25(\mathrm{OH}) \mathrm{D}(\mathrm{ng} / \mathrm{mL})$ & $27.86 \pm 13.52$ \\
Age group (years) & \\
$60-69$ & $144(50.7)$ \\
$70-79$ & $118(41.5)$ \\
$\geq 80$ & $22(7.8)$ \\
Schooling & \\
Literate & $40(14.1)$ \\
Primary school education incomplete & $195(68.7)$ \\
Basic education & $24(8.4)$ \\
Secondary education & $25(8.8)$ \\
Income* & \\
$\quad \leq$ US $\$ 4,200 /$ year & $163(62.0)$ \\
$>$ US $\$ 4,200 /$ year & $100(38.0)$ \\
Skin type & \\
I + II + III & $94(33.1)$ \\
IV + V + VI & $190(66.9)$ \\
\hline
\end{tabular}

Note: *Annual income equivalent in US\$, at the exchange rate of US\$I $=R \$ 1.65$. Abbreviations: 25(OH)D, 25 hydroxyvitamin D; BMl, body mass index; SD, standard deviation. lowest quartile (Q1) was 1.96 and the highest (Q4) was 7.86. Nonetheless, there was no statistical difference $(P=0.113)$ in serum 25(OH)D levels between Q1 (23.98 \pm 14.66$)$ and Q4 (29.88 \pm 13.78$)$, nor in the prevalence of hypovitaminosis D for the 20, 25, and $30 \mathrm{ng} / \mathrm{mL}$ cutoffs (Figure 2).

A low calcium intake was observed in $72 \%$ of the subjects and an annual family income of $\leq$ US $\$ 4,200$ in $64.5 \%$. There were no statistical differences between the groups with a low calcium intake and those with an intermediate and high intake at the three cutoffs for $25(\mathrm{OH}) \mathrm{D}$, nor were there between the groups with an annual income of $<$ US $\$ 4,200$ and of $>$ US $\$ 4,200$. A low level of education, defined as illiteracy or incomplete primary school education, was observed in $82.8 \%$ and only seven subjects $(2.5 \%)$ were using vitamin supplements.

Table 2 presents the results of the multivariate linear regression analysis to determinate the independent factors associated with vitamin $\mathrm{D}$ deficiency. The numerical variables included in the initial model were age, SI, and BMI. The dichotomous variables were income bracket, grouped skin phototype, vitamin D supplement use, calcium supplement use, and calcium intake. The variables remaining in the model were solar index, calcium intake, and BMI. The SI was independently associated with serum $25(\mathrm{OH}) \mathrm{D}$ levels.

\section{Discussion}

In this study of elderly men living in the tropics, vitamin D deficiency was found to be very common. Approximately one-third of participants presented with levels $<20 \mathrm{ng} / \mathrm{mL}$, and the majority - that is, two-thirds - presented with levels $<30 \mathrm{ng} / \mathrm{mL}$. Similar results were found in the Osteoporotic Fractures in Men Study (MrOS). In that study, 26\% and $72 \%$ of the elderly men presented with levels $<20$ and $<30 \mathrm{ng} / \mathrm{mL}$, respectively. Despite the similarity in results, we had expected that the prevalence of deficiency would be much lower in our region, given that the individuals studied live in an area with abundant sunlight and the blood collection was performed in the sunniest months of the summer. Since the MrOS study did not use SI as a clinical parameter, we could not compare this variable in the two studies. A fact that might account for the high prevalence in this region despite the high SI is the increased prevalence of individuals considered to have dark skin according to Fitzpatrick's classification ${ }^{15}$ as well as a high BMI. The MrOS study, after bivariate analysis, demonstrated that black people are independently associated with a high prevalence of vitamin D deficiency, with a 2.4-fold greater risk of deficiency than white people.

Melhus et al, in a cohort study carried out in Sweden with elderly men, demonstrated that the prevalence of vitamin D 


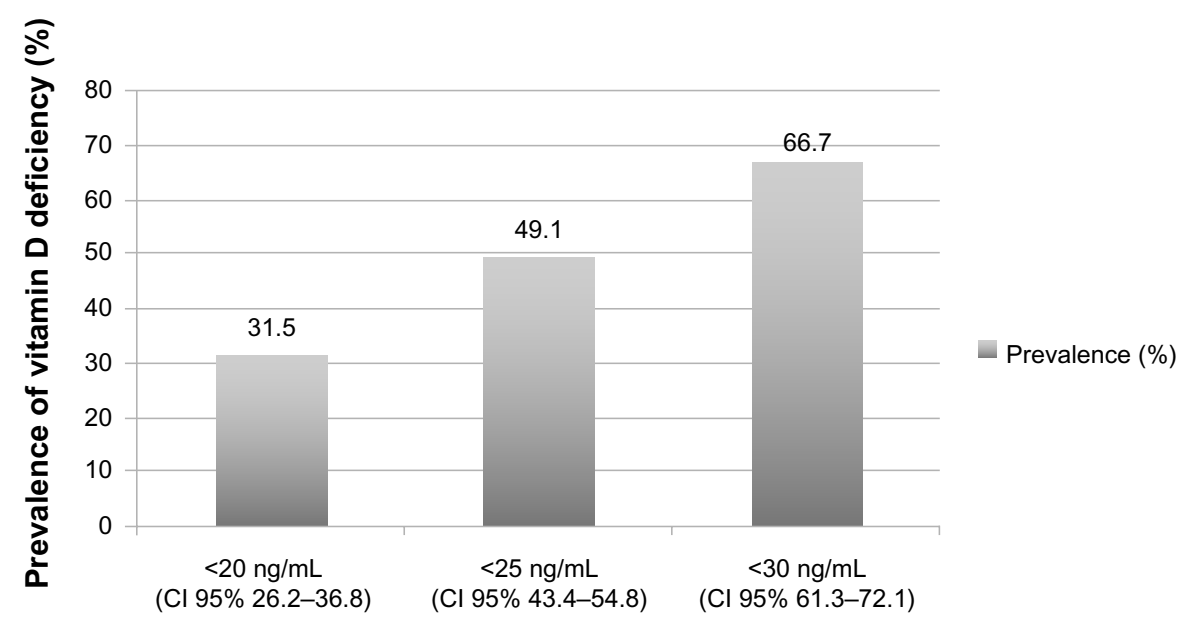

Figure I Prevalence of vitamin D deficiency in elderly men according to serum 25 hydroxyvitamin D level.

Abbreviation: $\mathrm{Cl}$, confidence interval.

deficiency, despite limited sun exposure in the winter and high latitude $\left(60^{\circ} \mathrm{N}\right)$, was rare for the $16 \mathrm{ng} / \mathrm{mL}$ cutoff..$^{18}$ The mean serum 25(OH)D level was $27.5 \mathrm{ng} / \mathrm{mL}$, which is similar to that of our patients $(27.9 \mathrm{ng} / \mathrm{mL})$. These data show that sun exposure in itself is not the preponderant factor in the prevention of $25(\mathrm{OH}) \mathrm{D}$ deficiency.

In relation to sun exposure, it may be observed that in the population with greatest SI (Q4), when compared with the least exposed group (Q1), no significant differences in mean serum 25(OH)D levels for the three cutoffs studied were observed, which suggests that the sun has little effect in preventing vitamin D deficiency in this population. In addition, the mean serum 25(OH)D in Q4 was $29.8 \mathrm{ng} / \mathrm{mL}$, demonstrating that, despite maximum sun exposure, mean $25(\mathrm{OH}) \mathrm{D}$ levels remained below $30 \mathrm{ng} / \mathrm{mL}$. Binkley et al ${ }^{19}$ demonstrated a prevalence of $25(\mathrm{OH}) \mathrm{D}$ deficiency of $51 \%$, using the $30 \mathrm{ng} / \mathrm{mL}$ cutoff, in a population of young surfers (mean age 24 years) in Hawaii $\left(20^{\circ} \mathrm{N}\right)$ with a mean SI of $11.1 \pm 0.7$. Similarly, low serum $25(\mathrm{OH}) \mathrm{D}$ levels were observed in workers with a mean SI $11.5^{14}$ and in two of 18 Puerto Rican farmers with a weekly sun exposure of 32-70 hours. ${ }^{20}$

In our study, the prevalence of dark-skinned patients (types IV, V, and VI) was $66.9 \%$. When comparing prevalence according to skin type (dark vs light) for each serum $25(\mathrm{OH})$ D cutoff, we found no significant difference $(P=0.46)$. Harris et al found a significant difference between black and white people with regard to the prevalence of low 25(OH)D concentration. ${ }^{16}$ While $28 \%$ of elderly white men presented levels below the $20 \mathrm{ng} / \mathrm{mL}$ cutoff, the corresponding figure for elderly black men was $73.1 \%(P<0.001) .{ }^{15}$ These data are in agreement with Loomis' observation that black people produce less vitamin D than white people at normal levels of sun exposure. ${ }^{21}$ The majority of the individuals in our study $(45.7 \%)$ had a skin color classified as intermediate (type III and IV). The number of individuals classified in

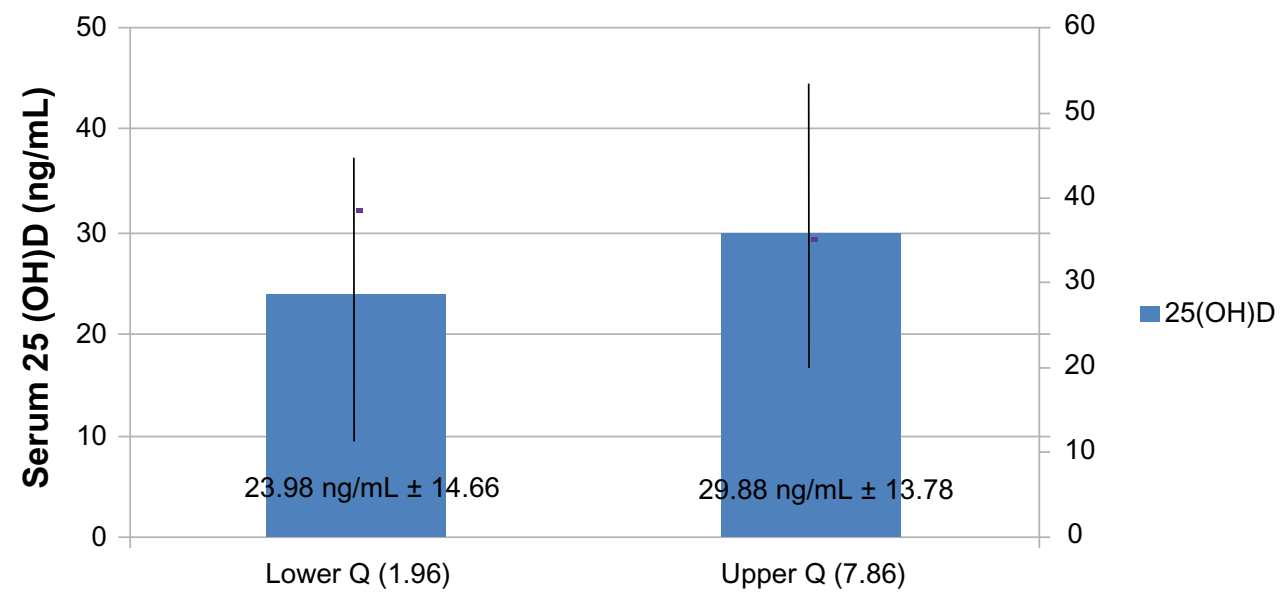

Figure 2 Serum 25 hydroxyvitamin $\mathrm{D}(25(\mathrm{OH}) \mathrm{D})$ levels (mean \pm standard deviation) according to sun index quartile $(\mathrm{Q})$. 
Table 2 Factors independently associated with 25 hydroxyvitamin $\mathrm{D}$ deficiency after linear regression

\begin{tabular}{llll}
\hline Variable & \multicolumn{2}{l}{ Coefficient } & P-value \\
\cline { 2 - 3 } & $\begin{array}{l}\text { Non- } \\
\text { standardized }\end{array}$ & Standardized & \\
\hline Sun index & 0.410 & 0.152 & $0.016^{*}$ \\
Body mass index $\left(\mathrm{kg} / \mathrm{m}^{2}\right)$ & -0.363 & -0.112 & 0.075 \\
Calcium intake $(\mathrm{mg} / \mathrm{day})$ & 3.067 & 0.097 & 0.125 \\
Constant & 32.911 & & \\
$R$ & 0.049 & & \\
$R^{2}$ & 0.222 & & \\
\hline
\end{tabular}

Note: *Significant at $5.0 \%$.

the extremes for skin color was very low (four whites and 33 blacks), making comparative analysis misleading.

In our study, $72 \%$ had a low calcium intake and only $2.5 \%$ $(n=7)$ used vitamin supplements. It should be emphasized that the number of food items enriched with vitamin $\mathrm{D}$ is low in Brazil. These numbers differ considerably from those of North America, where $24 \%$ of black and $44 \%$ of white elderly men and women studied were on vitamin D supplements. ${ }^{22}$ In this regard, Forrest and Stuhldreher demonstrated a high prevalence of vitamin D deficiency among a group of Americans, particularly in those who were black, obese, and illiterate and in those with a low milk intake $(P<0.05){ }^{23}$

As this study was not a population-based study, the results cannot be translated to the general population.

\section{Conclusion}

We found a high prevalence of vitamin D deficiency in elderly men living in the tropics, despite their high exposure to the sun in the summer months.

\section{Disclosure}

The authors declare no conflicts of interest in this work.

\section{References}

1. Orwoll E, Nielson CM, Marshall LM, et al; Osteoporotic Fractures in Men (MrOS) Study Group. Vitamin D deficiency in older men. J Clin Endocrinol Metab. 2009;94(4):1214-1222.

2. Holick MF. Vitamin D deficiency. N Engl J Med. 2007;357(3): 266-281.

3. Rosen CJ. Clinical practice. Vitamin D insufficiency. $N$ Engl J Med. 2011;364(3):248-254

Clinical Interventions in Aging

\section{Publish your work in this journal}

Clinical Interventions in Aging is an international, peer-reviewed journal focusing on evidence-based reports on the value or lack thereof of treatments intended to prevent or delay the onset of maladaptive correlates of aging in human beings. This journal is indexed on PubMed Central, MedLine, the American Chemical Society's 'Chemical Abstracts
4. Bandeira F, Griz L, Dreyer P, Eufrazino C, Bandeira C, Freese E. Vitamin D deficiency: A global perspective. Arq Bras Endocrinol Metabol. 2006;50(4):640-646.

5. Mosekilde L. Vitamin D and the elderly. Clin Endocrinol (Oxf). 2005;62(3):265-281.

6. MacLaughlin J, Holick MF. Aging decreases the capacity of human skin to produce vitamin D3. J Clin Invest. 1985;76(4):1536-1538.

7. Holick MF. Environmental factors that influence the cutaneous production of vitamin D. Am J Clin Nutr. 1995;61(Suppl 3):638S-643S.

8. Dawson-Hughes B, Heaney RP, Holick MF, Lips P, Meunier PJ, Vieth R. Estimates of optimal vitamin D status. Osteoporos Int. 2005;16: 713-715.

9. Lips P. Which circulating level of 25-hydroxyvitamin D is appropriate? J Steroid Biochem Mol Biol. 2004;89-90(1-5):611-614.

10. Bandeira F, Griz L, Freese E, et al. Vitamin D deficiency and its relationship with bone mineral density among postmenopausal women living in the tropics. Arq Bras Endocrinol Metabol. 2010;54(2):227-232.

11. Ensrud KE, Taylor BC, Paudel ML, et al; Osteoporotic Fractures in Men Study Group. Serum 25-hydroxyvitamin D levels and rate of hip bone loss in older men. J Clin Endocrinol Metab. 2009;94(8):2773-2780.

12. Heaney RP. Functional indices of vitamin D status and ramifications of vitamin D deficiency. Am J Clin Nutr. 2004;80(Suppl 6):1706S-1709S.

13. Kuchuk NO, Pluijm SM, van Schoor NM, Looman CW, Smit JH, Lips P. Relationships of serum 25-hydroxyvitamin D to bone mineral density and serum parathyroid hormone and markers of bone turnover in older persons. J Clin Endocrinol Metab. 2009;94(4):1244-1250.

14. Barger-Lux MJ, Heaney RP. Effects of above average summer sun exposure on serum 25-hydroxyvitamin D and calcium absorption. J Clin Endocrinol Metab. 2002;87(11):4952-4956.

15. Fitzpatrick TB. The validity and practicality of sun-reactive skin types I through VI. Arch Dermatol. 1988;124(4):869-871.

16. Harris SS, Soteriades E, Coolidge JA, Mudgal S, Dawson-Hughes B. Vitamin D insufficiency and hyperparathyroidism in a low income, multiracial, elderly population. J Clin Endocrinol Metab. 2000;85(11): 4125-4130.

17. Ersfeld DL, Rao DS, Body JJ, et al. Analytical and clinical validation of the $25 \mathrm{OH}$ vitamin D assay for the LIAISON automated analyzer. Clin Biochem. 2004;37(10):867-874.

18. Melhus H, Snellman G, Gedeborg R, et al. Plasma 25-hydroxyvitamin $\mathrm{D}$ levels and fracture risk in a community-based cohort of elderly men in Sweden. J Clin Endocrinol Metab. 2010;95(6):2637-2645.

19. Binkley N, Novotny R, Krueger D, et al. Low vitamin D status despite abundant sun exposure. J Clin Endocrinol Metab. 2007;92(6): 2130-2135.

20. Haddock L, Corcino J, Vazques MD. 25(OH)D serum levels in the normal Puerto Rican population and in subjects with tropical sprue and parathyroid disease. Puerto Rican Health Sciences Journal. 1982;1:85-91.

21. Loomis WF. Skin-pigment regulation of vitamin-D biosynthesis in man. Science. 1967;157(3788):501-506.

22. Dawson-Hughes B. Racial/ethnic considerations in making recommendations for vitamin $\mathrm{D}$ for adult and elderly men and women. Am J Clin Nutr. 2004;80(Suppl 6):1763S-1766S.

23. Forrest KY, Stuhldreher WL. Prevalence and correlates of vitamin D deficiency in US adults. Nutr Res. 2011;31(1):48-54.

Service' (CAS), Scopus and the Elsevier Bibliographic databases. The manuscript management system is completely online and includes a very quick and fair peer-review system, which is all easy to use. Visit http://www.dovepress.com/testimonials.php to read real quotes from published authors. 